\title{
Accounting Conservatism in Indonesia
}

\author{
Rini Indriani ${ }^{1}$ and Fachruzzaman ${ }^{2}$ \\ \{rini.indriani@gmail.com\} \\ Department Of Economy and Business, Universitas Bengkulu, Bengkulu, Indonesia
}

\begin{abstract}
This study aims to indicate the existence of accounting conservatism in financial reporting, and can provide a portrait application of conservatism in Indonesia, This study uses descriptive research design, which aims to indicate the presence of conservatism in financial reporting of non-financial companies in Indonesia from 2011 to 2015 using the conservatism index Q-Score indicating conservatism in the income statement, and the conservatism proxy of the C-score index to determine the level of conservatism on the balance sheet (financial position statement). The results of this study indicated that there is an association of accounting conservatism in the income statement with conservatism in the balance sheet (financial position report), for generalization it is suggested in subsequent researchers to verify. The results of this study are based on QScore Index and C-Score, so it cannot draw conclusions on other proxies.
\end{abstract}

Keywords: Conservatism, Q-Score, C-Score

\section{Introduction}

Accounting is a process to provide an organization's financial information about the financial position and company performance that can be used by interested parties in the decision-making process. Presentation of such financial information must have prudential conditions in measuring the assets and profits due to activity and business surrounded by an uncertainty. Generally accepted accounting principles provide flexibility in determining accounting methods and estimates that can be used. Such flexibility will affect the behavior of managers in the recording of accounting and corporate financial reporting. A manager must, under conditions of hesitation, apply conservative accounting principles (Nugroho, 2012).

Accounting conservatism is not a principle set forth in international accounting standards (IFRS). IFRS, compared to conventional accounting, focuses on more relevant records leading to increased dependence on forecasts and assessments. In this regard, the policy set by the IASB (International Accounting Standard Board) leads to a reduction of emphasis on consistent application of conservative accounting in IFRS-based financial reporting. Although conservatism is not depressed by IASB, uncertainty still faces the company in presenting the account. However, empirical evidence indicates a consistent conservative management behavior in relation to the presentation of multiple accounts. (Hellman, 2008).

Based on the background described earlier, this study aims to indicate the existence of accounting conservatism in financial reporting, and can provide a portrait application of conservatism in Indonesia. The measurement of conservatism in this study uses Givoly and Hayn (2000) proxies using conservatism index (Q-Score) to determine the level of conservatism in the income statement, and Penman and Zhang proxy (2002) using index conservatism (C-score) to know the level of conservatism on the balance sheet. 


\section{Literature Review}

\subsection{Accounting Conservatism}

According to the FASB Statement of Concept No.2 in Nugroho (2012), conservatism is a cautious reaction to deal with the uncertainty in trying to ensure that the uncertainties and risks to the business situation have been considered. Givoly and Hayn (2000) define conservatism as an initial recognition of costs and losses and delay recognition for income and profits. As Penman and Zhang (2002) explain accounting conservatism is a selection of accounting methods and estimates that keep the book value of net assets relatively low.

\subsection{Measurement of Accounting Conservatism}

Watts (2003) divides conservatism into 3 measurements, namely Earning/Stock Return Relation Measure, Earning/Accrual Measures, Net Asset Measure. Various researchers have proposed various methods of measuring conservatism. The following describes some measures of conservatism if grouped in accordance with Watt's approach (2003) in Amalia (2017):

1) Earning /Stock Return Relation Measure

Stock market price attempts to reflect changes in asset value at the time of change, either changes in loss or fixed income are reported in due course. Basu (1997) states that conservatism causes events that are bad news or good news reflected in unequal earnings (asymmetry of recognition time), since events that are expected to cause harm to the firm must be recognized immediately resulting in bad news more quickly reflected in profit compared good news.

2) Earning / Accrual Measures

a. The Givoly and Hayn Models (2000)

Dwiputro (2010) in his paper explains that Givoly and Hyan have focused conservatism on the income statement for several years. They argue that conservatism results in continuous negative accruals. Accrual in question is the difference between net income before depreciation / amortization and cash flows of operating activities. The greater the negative accruals the more conservative accounting will be applied. This is based on the theory that conservatism delayed the recognition of income and accelerated the use of costs. Conservatism's consolidated income statement thus delays the recognition of unrealized revenues and expenses incurred during that period compared to and made back-up on the balance sheet. Conversely, optimistic financial statements will tend to have higher net income compared to operating cash flow so that the resulting accrual is positive. Depreciation is excluded from net income in the calculation of CONACC for depreciation is the cost allocation of the assets owned by the company. At the time of asset purchase, cash paid is included in the cash flows from investing activities and not from operating activities. Thus, the allocation of depreciation expense in net income is not related to operating activities and must be excluded from the calculation.

b. Model Zhang (2008)

Zhang (2008) in his research used conv_accrual as one of the measurements of conservatism. Conv_accrual is obtained by dividing non-operating accruals with total assets. Non-operating accruals show the recording of adverse events occurring within the company, for example the cost of restructuring and asset removal. In his research Zhang (2008) multiplies the conv_accrual with -1 , it is intended to facilitate the analysis. Where, 
the higher conv_accrual value that has been obtained indicates that the application of conservatism in the company is also higher.

c. Discretionary Accrual

Another accrual model that can also be used as a measure of conservatism is the discretionary accruals model. There are several models for calculating Discretionary Accrual. The most commonly used Discretionary Accrual is the Kasznik discretionary accrual model (1999). Kasznik (1999) modified the Dechow et al. (1995) model by incorporating the operational cash flow difference $(\triangle \mathrm{CFO})$ to obtain non-discretionary accruals and discretionary accruals. Because Kasznik (1999) argues that changes in cash flows from the results of the operations of the company will be negatively correlated to the total accruals.

3) Net Asset Measure

The third measure used to determine the level of conservatism in the financial statements is the value of the asset understatement and the liability of the overstatement. One measurement model is the measurement proxy used by Beaver and Ryan (2000) and Penman and Zhang (2002) by using market to book ratio that reflects the market value relative to the book value of the company. A ratio of more than 1, indicating a conservative accounting application for the firm records the company's value lower than its market value.

\section{Methods}

This research uses descriptive research design, which aims to indicate the existence of conservatism in financial reporting of companies in Indonesia by using Givoly and Hayn (2000) proxies using conservatism index (Q-Score) to know the level of conservatism in profit and loss, and proxy Penman and Zhang (2002) who use index conservatism (C-score) to know the level of conservatism on the balance sheet (financial position statement).

1) Conservative proxy model of Givoly and Hayn (Q-Score)

$$
\mathrm{CON}=\frac{\mathrm{OACC}}{\mathrm{TA}} \times(-1)
$$

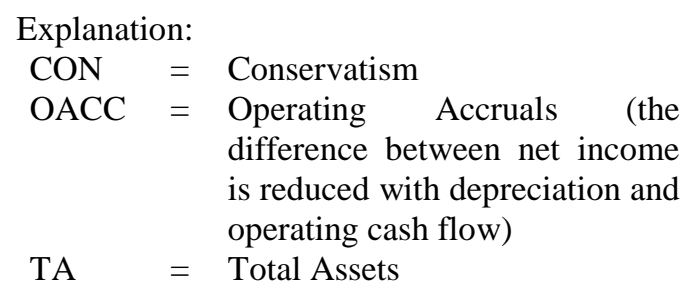

Accrual growth can be an index of conservative accounting shifts over the long-term period, so if accruals increase, conservatism will decrease and vice versa. For this reason, accruals are multiplied by -1 to determine the direction of conservatism change.

2) Conservative proxy model of Penman and Zhang (C-score)

$$
\mathrm{C}_{\mathrm{it}}=\frac{\mathrm{RP}_{\mathrm{it}}+\mathrm{DEPR}_{\mathrm{it}}}{\mathrm{NOA}_{\mathrm{it}}}
$$




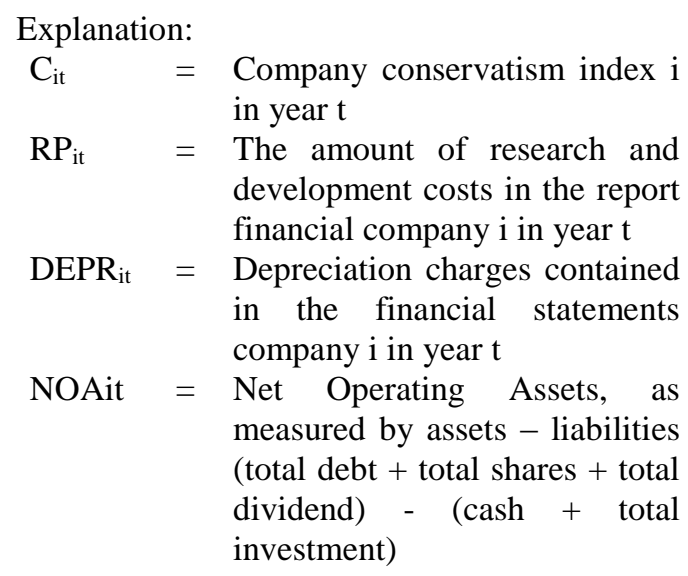

After the result of the proxy of each conservatism is obtained, then calculating the level of conservatism (high and low) for each proxy. It is intended to know high levels of conservatism and low conservatism firms. The symbol for the level of accounting conservatism in each company is DCON. DCON is a dummy conservatism where high conservatism will be measured. Companies with a high level of conservatism will be worth 1 which means that the company's conservatism is negative for Q-Score. And 0 for companies with a low level of conservatism that has a positive value conservatism. Otherwise, companies with a high level of conservatism will be worth 1 meaning the value of the conservatism of the company is positive for $\mathrm{C}$-Score. And 0 for companies with a low level of conservatism that has a negative value of conservatism.

The sample of this study is a non-financial company listed on the Indonesia Stock Exchange. Following Amalia's research (2017), the data used is secondary data from the company's annual report of the sample obtained from the research data through idx.go.id and traced from the web address of the company entered as the sample research.

\section{Result And Discussions}

\subsection{Population and Observation}

Registered non-financial companies amounted to 447 companies, and based on the criteria for purposive sampling, the company observed in the study amounted to 248 companies. Observations were made over five (5) years so that there were 1240 observations. Table 1 presents the number of companies for preliminary observation.

Table 1: Number of Companies for Initial Observation

\begin{tabular}{|c|c|c|}
\hline Criteria & Number & Percentage $(\%)$ \\
\hline Non-financial companies 2011-2015 & 447 & 100 \\
\hline The companies do not have complete data & (28) & $(6,3)$ \\
\hline Companies listed on BEI after 2010 & (104) & $(23,2)$ \\
\hline $\begin{array}{l}\text { Companies reporting financial statements in } \\
\text { currencies other than rupiah }\end{array}$ & (66) & $(14,8)$ \\
\hline Companies that move sectors & (1) & $(0,2)$ \\
\hline
\end{tabular}




\begin{tabular}{lcc}
\hline Number of companies meeting the criteria & 248 & 55,5 \\
Year of Observation & 5 & \\
Total Observations & $\mathbf{1 2 4 0}$ & $\mathbf{5 5 , 5}$ \\
\hline
\end{tabular}

The next stage, 248 companies that complied with accounting conservatism used Givoly and Hayn's proxy (2000) using conservatism index (Q-Score) to know the level of conservatism in the income statement, and Penman and Zhang (2002) proxy using conservatism index ( $\mathrm{C}$-score) to determine the level of conservatism on the balance sheet. Table 2 shows the number of observations based on the Q-Score and C-score indexes.

Table 2: Number of Observations By Index Q-Score and C-score

\begin{tabular}{lccc}
\hline Category & Dummy & $\begin{array}{c}\text { Numbe } \\
\text { r (n) }\end{array}$ & $\begin{array}{c}\text { Percent } \\
(\mathbf{\%})\end{array}$ \\
\hline $\begin{array}{l}\text { Q-Score Index } \\
\text { Implementing }\end{array}$ & 1 & 491 & 40 \\
$\begin{array}{l}\text { Conservatism } \\
\text { Not Implementing } \\
\text { Total }\end{array}$ & 0 & 749 & 60 \\
& & 1240 & 100 \\
C-Score Index & & \\
$\begin{array}{c}\text { Implementing } \\
\text { Conservatism }\end{array}$ & 1 & 1195 & 96 \\
$\begin{array}{c}\text { Not Implementing } \\
\text { Total }\end{array}$ & 0 & 45 & 4 \\
\hline
\end{tabular}

Based on Table 2 issues that using the Q-Score Index obtained 491 observations and CScore 1200 observations which will be further observed in this study. The result indicates that $491(40 \%)$ observations are indicated to apply accounting income conservatism, and 1195 (96\%) apply balance sheet accounting conservatism. Givoly and Hayn (Q-Score, 2000) define conservatism as a preliminary recognition of costs, losses and delay recognition for income, and profits. As Penman and Zhang (C-Score, 2002) explain accounting conservatism is a selection of methods and accounting estimates keeping the book value of net assets relatively low. The description of the data in this study can be seen from the mean, maximum, minimum and standard deviations of the conservatism index used in this study. Descriptive statistics in this study can be seen in Table 3

Table 3: Descriptive Statistics

\begin{tabular}{llllll}
\hline & N & \multicolumn{1}{c}{ Min } & \multicolumn{1}{c}{ Max } & Mean & Standard Deviation \\
\hline QScore* & 491 & -0.0003 & -7.5384 & -0.0923 & 0.4002 \\
CScore & 119 & 0.0001 & 1.5277 & 0.0305 & 0.0913 \\
& 5 & & & & \\
\hline
\end{tabular}

Table 3 shows that conservatism in relation to the balance sheet is more common than in profit and loss (1195> 491). The average conservatism with QScore is -0.0923 or $-9.23 \%$ of total assets, with a standard deviation> averages, the level of QScore conservatism varies. The average conservatism with CScore is 0.0305 or $3.05 \%$ of net operating asset, with a standard deviation> average, the level of C-Score conservatism varies. Table 4 is a conservatism matrix of Q-Score and C-Score. 
Table 4: Conservatism Matrix Q-Score and C-Score

\begin{tabular}{ccccc}
\hline & & \multicolumn{2}{c}{ C-Scores } & Total \\
& & 0 & $\mathbf{1}$ & \\
\hline Q-Scores & $\mathbf{0}$ & 0 & 55 & 55 \\
& $\mathbf{1}$ & 4 & 189 & 193 \\
Total & & 4 & 244 & 248 \\
\hline
\end{tabular}

\subsection{Conservatism with the Q-Score Index}

Table 4 shows accounting conservatism using the Q-Score Index. it is known that 193 of the $248(78 \%)$ companies are indicated to have practiced accounting conservatism in the period 2011-2015. Of the 193 companies a number of 14 companies are indicated to practice conservative accounting throughout 2011 - 2015 respectively. This result can be concluded that conservative accounting practice refers to Givoly and Hayn's proxies (Q-Score, 2000) defines conservatism as initial recognition for costs, losses, deferred recognition for income and profit over the 2011-2015 reporting period merely about $7.3 \% 193$ companies do accounting conservatism in their financial statements.

\subsection{Conservatism with Index C-Score}

Referring to Table 4 presenting accounting conservatism using Index C-Score, it is known that 244 of $248(98 \%)$ companies are indicated to have practiced accounting conservatism in the period 2011-2015. In addition, of the 244 firms 234 companies are indicated in conservative accounting practices throughout 2011 - 2015 respectively. This result can be concluded that conservative accounting practice refers to Penman and Zhang's proxy (C-Score, 2002) explains accounting conservatism as an election of accounting methods and estimates that keep the book value of net assets relatively low. The reporting period of 2011 - 2015 is commonly performed by non-financial companies, ie $96 \%$ of the 244 companies perform accounting conservatism in their financial statements.

\subsection{Conservatism with Index Q-Score and C-Score}

Linking conservatism with the Q-Score and C-Score indexes indicates that if the firm conservatively uses the Q-Score index then C-Score identifies the accounting conservatism. Solely 8 observations from $491(2 \%)$ are authenticated in conservative accounting practices. Conversely, if the company does not identify accounting conservatism using C-Score then QScore also does not indicate the existence of accounting conservatism, that is 8 observations from $40(20 \%)$ indicated by conservative accounting practices.

\section{Conclusion}

Based on the background, objectives, and discussion of this research, the portrait of the application of accounting conservatism in financial reporting in Indonesia is as follows:

a. Non-financial companies in Indonesia generally still apply the principle of conservatism, especially on the balance sheet (financial position report), namely by the selection of methods and accounting estimates that keep the book value of net assets relatively low. 
b. The financial statements of non-financial companies in Indonesia identified as accounting conservatism in the income statement through initial recognition of costs, losses and deferred recognition for income and profits. The Company engages in accounting conservatism practice on the statement of financial position (balance sheet).

The results of this study indicate that there is an association of accounting conservatism in the income statement with conservatism in the balance sheet (financial position report), for generalization is suggested in subsequent researchers to verify. The results of this study are based on the proxy used is the Q-Score Index and C-Score, so it cannot draw conclusions on other proxies.

\section{Reference}

[1] Amalia, Rizki Marfirani. "Pengaruh Konservatisme Akuntansi terhadap Reaksi Investor (Studi Empiris pada Perusahaan Non Keuangan yang Terdaftar di Bursa Efek Indonesia)". Skripsi Program Studi Akuntansi Fakultas Ekonomi dan Bisnis-Universitas Bengkulu. 2017

[2] Basu, Sudipta. "The Conservatism Principle and The Asymmetric Timeliness of Earnings". Journal of Accounting and Ecconomic 24, pp. 3-37. 1997.

[3] Beaver, W.H., and Ryan, S.G. "Biases and lags in book value and their effects on the ability of the book-tomarket ratio to predict book return on equity". Journal of Accounting Research 38, pp.127-148. 2000.

[4] Dwiputro, Dibyo. Hubungan Antara Konservatisme Akuntansi dengan Konflik Antara Pemegang Saham dan Kreditur Terkait Kebijakan Deviden pada Perusahaan Manufaktur di Indonesia. Depok: Fakultas Ekonomi Universitas Indonesia. 2010. http://lib.ui.ac.id

[5] Givoly, D., dan C. Hayn. "The Changing Time-Series Properties of Earnings, Cash Flows and Accruals: Has Financial Reporting Become More Conservative ?". Journal of Accounting and Economics 29, 287-320. 2000

[6] Helmaan, Niclass. Accounting Conservatism under IFRS. Accounting in Europa Vol. 5 No.2, 71100. 2008.

[7] Kasznik, Ron. "On The Association between Voluntary Disclosure and Earning Management". Journal of Accounting Research 37 (1). 1999.

[8] Panman, S. H. dan X. J. Zhang. "Accounting Conservatism, The Quality of Earnings, and Stock Return". The Accounting Review, Vol. 77, No. 2, pp. 237-264. 2002.

[9] Nugroho, Yanuar. Konservatisme Akuntansi dalam Teori Keagenan. 2012. Online, diakses pada tanggal 7 Juni 2017 di http://yanuar-nugroho. blogspot.co.id/2012/07/akuntansi-

konservatisme.html

[10] Watts, R.L "Conservatism in Accounting Part I: Explanations and Implications". Working Paper. University of Rochester. 2003.

[11] Zhang, J. "The contracting benefits of accounting conservatism to lenders and borrowers". Journal of Accounting and Economics 45, 27-54. 2008. 